\title{
Short communication: In vitro ruminal fermentability of a modified corn cultivar expressing a thermotolerant $\alpha$-amylase
}

\author{
W. Hu, ${ }^{* 1}$ M. E. Persia, $\dagger^{2}$ and L. Kung Jr. ${ }^{* 3}$ \\ *Department of Animal and Food Sciences, University of Delaware, Newark 19716 \\ †Syngenta Biotechnology Inc., Research Triangle Park, NC 27709
}

\begin{abstract}
The fermentability of a corn cultivar that expresses a thermostable $\alpha$-amylase (CA3272) was evaluated under various in vitro conditions. The CA3272 corn was developed as a replacement to microbial enzyme additions during the high-temperature processing of corn to produce ethanol. The $\alpha$-amylase activity in the corn might have the potential for positive effects on ruminant performance if incorporated into the ration. Four corn cultivars were evaluated in an in vitro ruminal fermentation where the digestion of starch was measured after $6 \mathrm{~h}$. The cultivars included a flint corn, an opaque corn, CA3272, and its near-isogenic counterpart (IC). The flint corn produced less total volatile fatty acids (18.4 $\mathrm{m} M$ ) than the other 3 corns (average of $25.3 \mathrm{mM}$ ), supporting the fact that it had the highest concentration of prolamins, which are negatively associated with starch availability. A second 6-h in vitro ruminal fermentation evaluated mixtures of the CA3272 and IC corns (0, $25,50,75$, and $100 \%$ concentrations of CA3272). Total volatile fatty acid production was not different among treatments for any proportions of CA3272. In a third in vitro experiment, there was a small but significant difference in starch degradation of CA3272 compared with IC (90.6 vs. $89.7 \%$ ) but this difference is most likely not biologically relevant. In a fourth in vitro experiment, CA3272 and IC were incubated in water at 40 and $65^{\circ} \mathrm{C}$ for $24 \mathrm{~h}$. Degradation of starch from native amylase activity at $40^{\circ} \mathrm{C}$ was 1.99 and $1.60 \%$ for CA3272 and IC, respectively, but when they were incubated at $65^{\circ} \mathrm{C}$, starch degradation was 10.56 and $0.85 \%$ for CA3272 and IC, respectively. These data demonstrate that amylase activity in CA3272 is expressed at a high temperature $\left(65^{\circ} \mathrm{C}\right)$ but at the physiological temperature expected in a rumen of a cow $\left(39-40^{\circ} \mathrm{C}\right)$, expression of amylase
\end{abstract}

Received April 23, 2009

Accepted June 4, 2010.

${ }^{1}$ Current address: Akey, Lewisburg, OH 45338.

${ }^{2}$ Current address: Iowa State University, Ames 50011.

${ }^{3}$ Corresponding author: lksilage@udel.edu activity does not appear to be sufficient to have any positive (or negative) effects on ruminal metabolism.

Key words: corn, amylase, starch, rumen

The majority of ethanol in the United States is produced from corn (Zea mays L.) through wet- or drymilling processes. In both cases, starches in the corn are enzymatically hydrolyzed to sugars that are fed into fermenters containing yeasts for conversion into ethanol (Vermerris et al., 2007). Currently, $\alpha$-amylases produced from microbial fermentations are used commercially in the starch processing. Syngenta Biotechnology Inc. (Research Triangle Park, NC) has developed a thermostable $\alpha$-amylase enzyme (AMY797E) expressed in a corn cultivar (CA3272) with the ability to resist high temperatures associated with dry-grind ethanol production. The CA3272 cultivar could serve as the source of $\alpha$-amylase enzyme in the dry-grind ethanol process, replacing the need for addition of microbial-produced enzymes. The enzyme AMY797E is functionally similar to the thermostable, genetically engineered $\alpha$-amylases (e.g., Bacillus spp.) currently used and has a history of safe use in food and feed processing (Pariza and Johnson, 2001; Olempska-Beer et al., 2006).

To date, there have been no reported studies evaluating the potential of CA3272 as a feedstock for ruminants. Therefore, the objective of this study was to investigate the influence of genotype; that is, the genetically modified corn CA3272 and its near-isogenic corn counterpart (IC) on the digestion characteristics by ruminal microorganisms under in vitro conditions.

In experiment 1 , the fermentation potential of various corn hybrids on production of VFA from in vitro ruminal fermentation was evaluated. The hybrids included a flint and an opaque corn (described by Blasel et al., 2006) and CA3272 and IC corns (Syngenta Biotechnology Inc.). Samples were analyzed by the Soil and Forage Analysis Laboratory, University of WisconsinDepartment of Soil Sciences (Madison, WI) for DM, CP, ash, and fat (AOAC, 1995). Samples were also analyzed for soluble protein (Krishnamoorthy et al., 1983), starch (Ehrman, 1996), amylase-treated NDF (aNDF; Van Soest et al., 1991), baseline shift (Hoffman et al., 
Table 1. Characteristics of corn grains used in the study

\begin{tabular}{lcccc}
\hline & \multicolumn{4}{c}{ Corn hybrid $^{1}$} \\
\cline { 2 - 4 } Item & CA3272 & IC & Flint & Opaque \\
\hline DM, \% & 93.46 & 93.35 & 93.58 & 94.23 \\
CP, \% of DM & 9.28 & 9.29 & 12.44 & 12.64 \\
Soluble CP, \% of CP & 14.33 & 13.34 & 14.14 & 26.50 \\
Prolamin, \% of DM & 4.69 & 4.39 & 6.19 & 2.17 \\
Baseline shift ${ }^{2}$ & 4.4818 & 3.6398 & 5.2550 & 2.8758 \\
Starch, \% of DM & 69.59 & 64.91 & 63.80 & 12.89 \\
aNDF, $\%$ of DM & 8.99 & 12.64 & 3.75 \\
Fat, \% of DM & 2.74 & 2.75 & 3.92 & 1.71 \\
Ash, \% of DM & 1.29 & 1.20 & 1.47 & \\
${ }^{1}$ CA3272 = corn with a thermostable $\alpha$-amylase gene; IC $=$ a near-isogenic line of CA3272 corn; Flint $=\mathrm{a}$ \\
normal flinty corn; Opaque = a normal opaque corn. & & \\
${ }^{2}$ Near-infrared spectroscopy baseline shift (1040-1140 nm). &
\end{tabular}

2010), and prolamin content (Larson and Hoffman, 2008). The chemical composition and characteristics of the corns used are shown in Table 1. All grains were ground through an Udy mill (2-mm screen; Cyclone Sample Mill, Udy Corp., Fort Collins, CO). Two hundred fifty milligrams of corn sample was weighed into replicate $60-\mathrm{mL}$ serum bottles ( $\mathrm{n}=6$ per corn sample). Ruminal fluid was collected approximately $3 \mathrm{~h}$ postfeeding from a ruminally fistulated Holstein steer fed a TMR consisting of about $45 \%$ concentrate and $55 \%$ forage on a DM basis. The diet was formulated to meet or exceed the dietary requirements for a cow weighing $650 \mathrm{~kg}$ and producing $35 \mathrm{~kg}$ of milk/d (NRC, 2001). Ruminal fluid was maintained at $40^{\circ} \mathrm{C}$ under anaerobic conditions before use. The fluid and contents were strained through 8 layers of cheesecloth under anaerobic conditions. Within $45 \mathrm{~min}$ of sampling, $12 \mathrm{~mL}$ of strained ruminal fluid and $18 \mathrm{~mL}$ of prewarmed $\left(40^{\circ} \mathrm{C}\right)$ buffer solution (Kung and Hession, 1995) were added to $60-\mathrm{mL}$ serum bottles. Bottles without corn were used as blanks. Bottles containing all experimental ingredients were immediately gassed for $10 \mathrm{~s}$ with anaerobic-grade $\mathrm{CO}_{2}$ and crimp sealed with butyl rubber-lined stoppers. Bottles were incubated in a water bath maintained at $40^{\circ} \mathrm{C}$. Initial samples of ruminal fluid and buffer were sampled at time 0 , and all experimental bottles were sampled after $6 \mathrm{~h}$ of incubation (the fermentation was stopped immediately by addition of $0.1 \mathrm{~mL}$ of $50 \%$ $\mathrm{H}_{2} \mathrm{SO}_{4}$ ). Once the fermentations were stopped, $5 \mathrm{~mL}$ of sample was acidified with $25 \%$ meta-phosphoric acid (1 part of acid to 5 parts of sample) and centrifuged at $10,000 \times g$ for $10 \mathrm{~min}$ before being analyzed for VFA by gas chromatography (model 5890, Series II; Agilent Technologies Inc., Santa Clara, CA) with a 530- $\mu \mathrm{m}$ Carbowax 20M column and flame-ionization detector. The chromatograph oven was programmed as follows: $70^{\circ} \mathrm{C}$ for $1 \mathrm{~min}, 5^{\circ} \mathrm{C}$ increase $/ \mathrm{min}$ to $100^{\circ} \mathrm{C}$, $45^{\circ} \mathrm{C}$ increase $/ \mathrm{min}$ to $170^{\circ} \mathrm{C}$, and a final holding time of 5 min. Production of total VFA was calculated by subtracting the initial concentrations of total VFA from the final concentrations of total VFA after $6 \mathrm{~h}$ of incubation. Molar proportions of the VFA were calculated by dividing the concentration of individual acids by the total concentrations of VFA. Minor acids (isobutyric, butyric, isovaleric, and valeric) are not shown but were included in the calculation of total VFA.

In experiment 2 , the in vitro VFA production potential of CA3272 and IC were evaluated by incubating a set of mixtures of CA3272 and IC in rumen fluid and buffer for $6 \mathrm{~h}$. The mixtures were developed by mixing $100,75,50,25$, and $0 \% \mathrm{CA} 3272$ with $0,25,50,75$, and $100 \%$ IC on a DM basis, respectively. The experimental methods were the same as described for experiment 1 .

In experiment 3 , the in vitro ruminal starch degradability of CA3272 and IC was directly assessed. Samples of CA3272 and IC were ground as described in experiment 1, but via a 1-mm screen. Samples were analyzed in 5 replicates for starch content, using the amyloglucosidase $/ \alpha$-amylase method (total starch assay kit, Megazyme International, Wicklow, Ireland). Starch content was determined based on the measured glucose concentration and expressed as a percentage of DM. In vitro starch degradability procedures were as described previously with the following exceptions. Rumen fluid was strained through 8 layers of cheesecloth into a $500-\mathrm{mL}$ bottle gassed with $\mathrm{CO}_{2}$ and placed in a $40^{\circ} \mathrm{C}$ water bath for $20 \mathrm{~min}$. Settled and floating materials were discarded after separation. Six $60-\mathrm{mL}$ serum bottles containing $12 \mathrm{~mL}$ of this strained and separated ruminal fluid and $18 \mathrm{~mL}$ of buffer solution were prepared for each sample. Moreover, fermentation was stopped after $6 \mathrm{~h}$ by addition of $10 \mathrm{~mL}$ of cold $0.2 M$ acetate buffer ( $\mathrm{pH} 4.5$ ) and samples were stored at $-20^{\circ} \mathrm{C}$ until further analysis. Starch digestion was 
calculated by subtracting residual starch at time $6 \mathrm{~h}$ from the starting concentration of starch in the tube at time 0 .

In experiment 4 , the native amylase activity in CA3272 and IC corn was evaluated when the corns were incubated in water at various temperatures. One hundred milligrams of CA3272 and IC (ground via a 1-mm screen) were weighed into tubes for each of 5 replicate tubes per grain. Four milliliters of distilled water was added to each tube and all treatments were incubated at 40 and $65^{\circ} \mathrm{C}$ for $24 \mathrm{~h}$. Glucose contents of samples in the tubes at time 0 and $24 \mathrm{~h}$ after incubation in water were measured and starch was determined as described in experiment 3 .

Data were analyzed using the GLM procedure of SAS (SAS Institute, 2004). The treatment effect in experiments 1, 2, and 3 was tested with the model

$$
\mathrm{Y}_{\mathrm{i}}=\mu+\mathrm{T}_{\mathrm{i}}+\mathrm{e}_{\mathrm{i}}
$$

where $\mu=$ overall mean; $T_{i}=$ effect of treatment (in experiment 1, treatment was corn hybrid including CA3272, IC, flint, and opaque corns, $\mathrm{i}=1,2,3,4$; in experiment 2, treatment was CA3272, IC, and their combination of various proportions, $\mathrm{i}=1,2,3,4,5$; in experiment 3 , treatment was $\mathrm{CA} 3272$ and $\mathrm{IC}, \mathrm{i}=$ $1,2)$; and $\mathrm{e}_{\mathrm{i}}=$ error term. The multiple comparisons among treatment means in experiments 1 and 2 were conducted using Tukey's test. The effects of corn hybrid and incubating temperature, and their interaction in experiment 4 were tested with the model

$$
\mathrm{Y}_{\mathrm{i}}=\mu+\mathrm{C}_{\mathrm{i}}+\mathrm{A}_{\mathrm{j}}+(\mathrm{C} \times \mathrm{A})_{\mathrm{ij}}+\mathrm{e}_{\mathrm{ij}},
$$

where $\mu=$ overall mean; $\mathrm{C}_{\mathrm{i}}=$ effect of corn genotype $(\mathrm{i}=1,2) ; \mathrm{A}_{\mathrm{j}}=$ effect of temperature $(\mathrm{j}=1,2) ;(\mathrm{C} \times$ $A)_{i j}=$ effect of interaction of corn genotype and tem- perature; and $\mathrm{e}_{\mathrm{ij}}=$ error term. Significance for all 4 experiments was defined as $P<0.05$.

The effects of in vitro ruminal fermentation of various corn hybrids on VFA profiles in experiment 1 are shown in Table 2. Production of total VFA was greatest from opaque corn. Production of total VFA from CA3272 was similar to that from IC and both were intermediate to the total VFA production of the opaque and flint corns. Production of acetic acid from CA3272 was reduced compared with that from IC $(P<0.05)$, but no difference in production of propionic acid was observed between CA3272 and IC. The molar ratio of acetic to propionic acid was reduced for CA3272 compared with that from IC $(P<0.05)$. In experiment 2 , there were no significant differences in VFA production between various mixtures of CA3272 and IC (data not shown), which was consistent with those of experiment 1 . The production of VFA was used as an indicator of total starch fermentability because starch is the primary fermentable component in corn that would yield VFA. Sveinbjornsson et al. (2007) found that the amount of VFA produced after an 8-h in vitro incubation was closely correlated to the amount of starch degraded. The flint and opaque corns were included in experiment 1 as references to access in vitro starch fermentability via the production of VFA. The endosperm texture of the grain appears to play an important role in ruminal VFA production and starch degradation (Philippeau et al., 1999). The flint corn used in our study had a higher concentration of prolamins and greater baseline shift than the opaque corn and thus it had lower ruminal starch degradation than the opaque and other corns. The CA3272 and IC corns had intermediate amounts of prolamins and thus VFA production was between that of the flint and opaque corns. Overall, results suggest that the amylase enzyme in CA3272 had little effect on starch degradation as measured by VFA production under in vitro ruminal conditions.

Table 2. Production and profiles of VFA from corn hybrids incubated in ruminal fluid and buffer $\left(40^{\circ} \mathrm{C}\right)$ for $6 \mathrm{~h}$ (experiment 1)

\begin{tabular}{lccccc}
\hline & \multicolumn{4}{c}{ Corn hybrid $^{1}$} & \\
\cline { 2 - 4 } Item & CA3272 & IC & Flint & Opaque & SEM \\
\hline Total VFA, ${ }^{2} \mathrm{~m} M$ & $23.28^{\mathrm{b}}$ & $25.52^{\mathrm{ab}}$ & $18.37^{\mathrm{c}}$ & $27.18^{\mathrm{a}}$ & 0.74 \\
Acetic acid, $\mathrm{m} M$ & $12.99^{\mathrm{b}}$ & $14.82^{\mathrm{a}}$ & $10.57^{\mathrm{c}}$ & $16.18^{\mathrm{a}}$ & 0.48 \\
Propionic acid, $\mathrm{m} M$ & $7.54^{\mathrm{b}}$ & $7.62^{\mathrm{b}}$ & $6.18^{\mathrm{c}}$ & $8.79^{\mathrm{a}}$ & 0.22 \\
Acetic acid, molar \% & $0.56^{\mathrm{b}}$ & $0.58^{\mathrm{ab}}$ & $0.58^{\mathrm{ab}}$ & $0.60^{\mathrm{a}}$ & 0.008 \\
Propionic acid, molar \% & $0.32^{\mathrm{a}}$ & $0.30^{\mathrm{b}}$ & $0.34^{\mathrm{a}}$ & $0.32^{\mathrm{a}}$ & 0.004 \\
Ratio of acetic to propionic acid & $1.72^{\mathrm{c}}$ & $1.95^{\mathrm{a}}$ & $1.71^{\mathrm{c}}$ & $1.84^{\mathrm{b}}$ & 0.028 \\
\hline a-c Means within rows with unlike superscripts differ $(P<0.05)$. & & \\
${ }^{1}$ CA3272 = corn with a thermostable $\alpha$-amylase gene; IC $=$ a near-isogenic line of CA3272 corn; Flint $=\mathrm{a}$ \\
normal flinty corn; Opaque = a normal opaque corn. \\
${ }^{2}$ Isobutyric, butyric, isovaleric, and valeric acids were not reported but were included in the calculation of total \\
VFA.
\end{tabular}


Table 3. Starch degradability of CA3272 and IC corn hybrids ${ }^{1}$ incubated in water at 40 and $65^{\circ} \mathrm{C}$ (Temp.) for $24 \mathrm{~h}$ (experiment 4)

\begin{tabular}{|c|c|c|c|c|c|c|c|c|}
\hline \multirow[b]{2}{*}{ Item } & \multicolumn{2}{|c|}{$40^{\circ} \mathrm{C}$} & \multicolumn{2}{|c|}{$65^{\circ} \mathrm{C}$} & \multirow[b]{2}{*}{ SEM } & \multicolumn{3}{|c|}{ Effect $(P<)$} \\
\hline & CA3272 & IC & CA3272 & IC & & Corn & Temp. & Corn $\times$ temp. \\
\hline Starch degradability & 1.99 & 1.60 & 10.56 & 0.85 & 0.08 & $<0.01$ & $<0.01$ & $<0.01$ \\
\hline
\end{tabular}

${ }^{1} \mathrm{CA} 3272=$ corn with a thermostable $\alpha$-amylase gene; $\mathrm{IC}=$ a near-isogenic line of CA3272 corn.

A third experiment was conducted to directly measure potential differences in ruminal in vitro starch degradation between CA3272 and IC. A single time point determination of starch degradation in cereal grain has been employed and proved feasible in an in vitro system to evaluate starch disappearance (Wester et al., 1992; Richards et al., 1995). We chose a 6-h incubation time because it was used successfully to show differences in in vitro starch digestion in a previous study from our laboratory (Klingerman et al., 2009). In the present study we found that in vitro degradation of starch from CA3272 after $6 \mathrm{~h}$ was greater than that from IC, even though the actual difference was very small and probably not biologically relevant (90.6 vs. $89.7 \%, P<0.01$; data not shown).

The degradation of starch by amylase activity in $\mathrm{CA} 3272$ and IC in water at 40 and $65^{\circ} \mathrm{C}$ for $24 \mathrm{~h}$ (experiment 4) is shown in Table 3. Differences existed in degradation of starch between corn hybrids (CA3272 vs. IC; $P<0.01)$ and between incubation temperatures (40 vs. $65^{\circ} \mathrm{C} ; P<0.01$ ). The significant interaction effect between corn hybrid and incubation temperature $(P<0.01)$ was due to the relatively small difference in degradation of starch at $40^{\circ} \mathrm{C}$ and the large increase in degradation of starch with the CA3272 at $65^{\circ} \mathrm{C}$. This difference in temperature-dependent enzyme activity was expected because this enzyme was developed to have maximum activity at the high temperatures utilized in the corn to ethanol production process. This temperature-dependent activation readily explains why the enzyme has no effect or a very limited effect at rumen physiologic temperatures in our experiments. Because the expression of the amylase activity in CA3272 is dependent on a high temperature, feeding CA3272 to ruminants would not appear to be beneficial and we observed no detrimental effects of having this activity in corn.

\section{ACKNOWLEDGMENTS}

The study was partially financed by Syngenta Biotechnology Inc. (Research Triangle Park, NC). The authors thank P. C. Hoffman (Marshfield Ag Research Station, University of Wisconsin) for analytical assistance.

\section{REFERENCES}

AOAC. 1995. Official Methods of Analysis. 16th ed. AOAC. Arlington, VA.

Blasel, H. M., P. C. Hoffman, and R. D. Shaver. 2006. Degree of starch access: An enzymatic method to determine starch degradation potential of corn grain and corn silage. Anim. Feed Sci. Technol. 128:96-107.

Ehrman, T. 1996. Determination of starch in biomass samples by chemical solubilization and enzymatic digestion. LAP-016. US Dept. Energy, National Bioenergy Center, Washington, DC.

Hoffman, P. C., D. Ngonyamo-Majee, and R. D. Shaver. 2010. Determination of corn hardness in diverse corn germplasm using nearinfrared reflectance baseline shift as a measure of grinding resistance. J. Dairy Sci. 93:1685-1689.

Klingerman, C. M., W. Hu, E. E. McDonell, M. C. DerBedrosian, and L. Kung Jr. 2009. An evaluation of exogenous enzymes with amylolytic activity for dairy cows. J. Dairy Sci. 92:1050-1059.

Krishnamoorthy, U., C. J. Sniffen, M. D. Stern, and P. J. Van Soest. 1983. Evaluation of a mathematical model of rumen digestion and an in vitro simulation of rumen proteolysis to estimate the rumenundegraded dietary nitrogen content of the feedstuffs. Br. J. Nutr. 50:555-568.

Kung, L. Jr., and A. O. Hession. 1995. Preventing in vitro lactate accumulation in ruminal fermentations by inoculation with Megasphaera elsdenii. J. Anim. Sci. 73:250-256.

Larson, J., and P. C. Hoffman. 2008. A method to quantify prolamin proteins in corn that are negatively related to starch digestibility in ruminants. J. Dairy Sci. 91:4834-4839.

NRC. 2001. Nutrient Requirements of Dairy Cattle. 7th rev. ed. Natl. Acad. Sci., Washington, DC.

Olempska-Beer, Z. S., R. I. Merker, M. D. Ditto, and M. J. DiNovi. 2006. Food-processing enzymes from recombinant microorganisms-A review. Regul. Toxicol. Pharmacol. 45:144-158.

Pariza, M. W., and E. A. Johnson. 2001. Evaluating the safety of microbial enzyme preparations used in food processing: Update for a new century. Regul. Toxicol. Pharmacol. 33:173-186.

Philippeau, C., F. Le Deschault de Monredon, and B. Michalet-Doreau. 1999. Relationship between ruminal starch degradation and the physical characteristics of corn grain. J. Anim. Sci. 77:238-243.

Richards, C. J., J. F. Pedersen, R. A. Britton, R. A. Stock, and C. R. Krehbiel. 1995. In vitro starch disappearance procedure modifications. Anim. Feed Sci. Technol. 55:35-45.

SAS Institute. 2004. SAS System Software. Release 9.1 (TS1M3). SAS Institute Inc., Cary, NC.

Sveinbjornsson, J., M. Murphy, and P. Uden. 2007. In vitro evaluation of starch degradation from feeds with or without various heat treatments. Anim. Feed Sci. Technol. 132:171-185.

Van Soest, P. J., J. B. Robertson, and B. A. Lewis. 1991. Methods for dietary fiber, neutral detergent fiber, and non-starch polysaccharides in relation to animal nutrition. J. Dairy Sci. 74:3583-3597.

Vermerris, W., A. Saballos, G. Ejeta, N. S. Mosier, M. R. Ladisch, and N. C. Carpita. 2007. Molecular breeding to enhance ethanol production from corn and sorghum stover. Crop Sci. 47:S142-S153.

Wester, T. J., S. M. Gramlich, R. A. Britton, and R. A. Stock. 1992. Effect of grain sorghum hybrid on in vitro rate of starch disappearance and finishing performance of ruminants. J. Anim. Sci. 70:2866-2876. 